\title{
PENGEMBANGAN MATHEMATICS MOBILE LEARNING APPLICATION (MMLA)- SISTEM PERSAMAAN LINEAR DUA VARIABEL (SPLDV) UNTUK SISWA KELAS 8 SEBAGAI SUMBER PEMBELAJARAN MANDIRI BERBASIS ANDROID
}

\author{
Zefriyenni $^{1}$ \\ Hayatul Mardhiyah ${ }^{2}$
}

\begin{abstract}
ABSTRAK
In the education required changes in the application of the development of teaching and learning methods to improve student interest in learning mathematics, especially in doing mathematics problems class VIII about the system of linear equations two variables. The low ability of students in the learning process and workmanship problems caused by various factors, such as learning systems used are still conventional. Therefore, the author helps SMP N 1 Pariangan to transform the learning resources of the book into digital form in accordance with the development of mobile device technology today, by making a mobile learning application. Mobile learning application displays about two-variable linear equation system, displaying learning materials, news menu, and task upload system. The application is made in the form of mobile application for android based mobile devices. With this mobile learning application can improve the ability, and facilitate students in learning mathematics about the system of linear equations two variables.
\end{abstract}

Keywords: Android Internet, Mobile Application, Mobile Learning, Spldv.

\section{INTISARI}

Dalam dunia pendidikan diperlukan perobahan penerapan pengembangan metode belajar mengajar untuk meningkatkan minat siswa dalam belajar matematika, terutama dalam mengerjakan soal-soal matematika kelas VIII tentang sistem persamaan linear dua variable. Rendahnya kemampuan siswa dalam proses belajar dan pengerjaan soal disebabkan oleh berbagai faktor, diantaranya sistem pembelajaran yang digunakan masih bersifat konversional. Oleh sebab itu, penulis membantu SMP N 1 Pariangan untuk mentransformasikan sumber belajar dari buku ke dalam bentuk digital sesuai dengan perkembangan teknologi perangkat mobile saat ini, dengan membuat sebuah aplikasi mobile learning. Aplikasimobile learning ini menampilkan mengenai sistem persamaan linear dua variable, menampilkan materi belajar, menu berita, dan sistem upload tugas. Aplikasi dibuat dalam bentuk mobile application untuk perangkat mobile berbasis android. Dengan aplikasi mobile learning ini dapat meningkatkan kemampuan,dan memudahkan siswa dalam belajar matematika tentang sistem persamaan linear dua variable.

Kata Kunci : Android Internet, Mobile Application, Mobile Learning, Spldv.

\footnotetext{
1,2 Universitas Putra Indonesia "YPTK" Padang
} 


\section{PENDAHULUAN \\ Latar Belakang}

Perkembangan teknologi saat ini telah menciptakan pengembangan terobosan baru dalam dunia pendidikan. Dunia pendidikan yang nantinya akan mencetak generasi muda yang memilii kecerdasan otak sekaligus keterampilan yang tinggi. Tidak hanya memanfaatkan perkembangan alat kemajuan IPTEK untuk kepentingan yang kurang bermanfaat namun dapat bermanfaat bagi peningkatan mutu SDM di Indonesia.Generasi muda yang memiliki SDM yang tinggi saat ini yang dibutuhkan oleh bangsa Indonesia saat ini. Maka dari itu, dalam dunia pendidikan dierlukan perubahan penerapan pengembangan metode kegiatan belajar mengajar yang dahulu masih bersifat konversional kearah yang lebih modern dan efektif sehingga diharapkan proses kegiatan belajar mengajar lebih optimal dalam peran dan fungsionalnya. Penerapan pengembangan metode pembelajaran yang tepat untuk mengimbangi kemajuan teknologi saat ini yakni memanfaatkan perangkat bergerak dalam proses kegiatan belajar mengajar atau lebih dikenal dengan Mobile Learning, sehingga kemajuan perangkat mobile dapat dimanfaatkan dengan memberikan suatu aplikasi belajar siswaterutama siswa kelas 8, dengan memberikan model pembelajaran yang efektif dan dapat diakses kapanpun dan dimanapun.

Berdasarkan hasil penelitian terdahulu yang telah dilakukan oleh M.Irfan Aripurnamayana tahun 2011 yang membahas tentang perancangan dan pembuatan mobile learning berbasis android mata pelajaran sejarah, Dan hasil penelitian Ismaya Gharini yang membahas tentang pengembangan aplikasi mobile learning sebagai media pembelajaran matematika untuk materi peluang. Dimana aplikasi ini masih bersifat offline maka aplikasi ini tidak bisa di update secara dinamis. lis, maka dari itu penulis mencoba untuk mengembangkanaplikasi

pembelajaran tersebut menjadi aplikasi yang tidak hanya sebagai media pembelajaran yang biasa digunakan, namun aplikasi yang akan penulis rancang yaitu sebuah aplikasi dimana siswa dapat belajar dengan mudah dan guru juga bisa berinteraksi dengan siswanya melalui aplikasi ini .kemudian beberapa penjelasan dari metode akan diikuti dengan gambar mulai dari semua teori-teori dan lengkap dengan rumusnya dengan acuan matematika kelas VIII khususnya Sistem persamaan dua variable (SPLDV). Bahan ini merupakan bagian dari kurikulum dan diimplementasikan dalam kehidupan sehati-hari.

\section{Rumusan Masalah}

Berdasarkan latar belakang diatas, maka penulis dapat merumuskan rumusan masalah sebagai berikut :

1. Bagaimana merancang aplikasi pembelajaran yang mudah dioperasikan oleh siswa-siswi SMP kelas 8 mata pelajaran matematika?

2. Bagaimana informasi pembelajaran dapat ditampilkan pada smartphone android ?

3. Bagaimana data pembelajaran selalu update apabila ada penambahan materi atau tugas sehingga lebih cepat membantu dan informasi mudah diterima dengan smartphone pengguna?

4. Apakah aplikasi pembelajaran ini dapat dijadikan sebagai media penghubung antara guru dan 


\author{
siswa dalam proses belajar \\ mengajar?
}

\section{Hipotesa}

Hipotesa merupakan dugaan sementara atau pemecahan masalah yang bersifat sementara dimana nantinya akan dibuktikan dengan hasil penelitian yang dilakukan. Berdasarkan permasalahan yang ada dapat dikemukakan beberapa hipotesa sebagai berikut :

1. Aplikasi pembelajaran ini dapat mempermudah siswa-siswi dalam mempelajari mata pelajaran matematika dimanapun dan kapanpun.

2. Aplikasi pemebelajaran ini dapat ditampilkan pada smartphone android.

3. Data pembelajaran dapat selalu update apabila ada penambahan materi atau tugas sehingga lebih cepat membantu dan informasi mudah diterima dengan smartphone pengguna.

4. Aplikasi pembelajaran ini dapat dijadikan media penghubung antara guru dan siswa dalam proses belajar mengajar.

\section{Batasan Masalah}

Seiring dengan kemampuan penulis yang sangat terbatas, dan untuk mendapatkan informasi materi serta agar pembahasan tidak menyimpang dari tujuan maka dilakukan pembatasan masalah sebagai berikut :

1. Aplikasi M-Learning ini dibuat untuk dapat beroperasi pada perangkat mobile berbasis android.

2. Target pemakai aplikasi MLearning ini lebih di utamakan untuk siswa SMP kelas VIII.

3. Materi yang dimuat dalam aplikasi M-Learning ini adalah materi matematika dibatasi hanya tentang system persamaan linear dua variable (SPLDV) untuk kelas VIII yang terdiri atas :

a. Persamaan linear satu variable

b. Persamaan linear dua variable (PLDV)

c. Sistem Persamaan Linear Dua Variable (SPLDV)

d. Penyelesaian Sistem Persamaan Linear Dua Variable (SPLDV)

e. Penerapan Persamaan Linear Dua variable (SPLDV)

f. Soal Latihan

4. Aplikasi M-Learning ini dibuat untuk mempermudah komunikasi antara guru dan siswa dalam proses belajar mengajar.

\section{Tujuan dan Manfaat Penelitian}

1. Untuk merancang sebuah aplikasi yang mudah dioperasikan oleh siswa-siswi SMP kelas 8 mata pelajaran matematika

2. Untuk menampilkan informasi pembelajaran melalui smartphone android.

3. Untuk mempermudah update materi maupun latihan pada smartphone android.

4. Untuk dijadikan sebagai media penghubung antara guru dan siswa dalam proses belajar mengajar.

\section{PENDEKATAN DAN PEMECAHAN \\ MASALAH \\ Definisi Android}

Menurut Nazaruddin Safaat $\mathrm{H}$ (2014:1) Android adalah sebuah system operasi untuk perangkat mobile berbasis linux yang mencakup system operasi, middleware dan aplikasi.Android menyediakan platform terbuka bagi para pengembang untuk menciptakan aplikasi mereka.Awalnya, Google Inc. membeli android Inc. yang merupakan 
pendatang baru yang membuat peranti lunak untuk ponsel/smartphone. Kemudian untuk mengembangkan android, dibentuk Open Handset Alliance, konsorsium dari 34 perusaan peranti keras, peranti lunak, dan telekomunikasi, termasuk Google, HTC Intel, Motorola, Qualcomm, T-Mobile, dan Nvidia.

\section{Definisi Mobile Learning}

Menurut Yenni Anggraini, (2012:439) istilah mobile learning (Mlearning) mengacu kepada penggunaan perangkat IT genggam dan bergerak, seperti PDA, telepon genggam, laptop dan tablet $P C$, dalam pengajaran dam pembelajaran. Mlearning adalah pembelajaran yang unik karena pembelajar dapat mengakses materi pembelajaran, arahan dan aplikasi yang berkaitan dengan course kapanpun dan dimanapun. Hal ini akan meningkatkan perhatian pada materi pembelajaran, membuat pembelajar menjadai pervasive, dan dapat mendorong motivasi pembelajar kepada pembelajaran sepanjang hayat. Selain itu, dibandingkan pembelajaran konvensional, mlearning memungkinkan adanya lebih banya kesempatan untuk kolaborasi secara ad hocdan berinteraksi secara informal diantara pembelajar.

\section{Definisi UML}

Menurut Rosa A.S dan M.Shalahudin, (2014:25) Bahasa pemograman berorientasi objek pertama kali dikembangkan dikenal dengan nama Simula-67 yang dikembangkan pada tahun 1967. Bahasa pemograman ini kurang berkembang dan dikembangkan lebih lanjut, namun dengan kemunculannya telah memberikan sumbangan yang besar pada developer pengembangan bahasa pemograman berorientasi objek selanjutnya.

\section{Definisi Java}

Menurut Jubile enterprise, (2014:2) bahasa pemograman java dikembangkan oleh Sun Microsystem yang dimulai oleh james Gosling dan dirilis pada tahun 1995. Saat ini sun microsystem telah diakuui oleh Oracle Corporation.

Java bersifat Write Once, Run Anywhere (program yang ditulis satu kali dan dapat berjalan pada banyak platform).

\section{ANALISA DAN PERANCANGAN Analisa Sistem}

Untuk membangun suatu sistem atau perangkat lunak terlebih dahulu perlu dilakukan analisa. Analisa merupakan proses penguraian dan identifikasi komponen untuk menemukan permasalahan dan kemudian mencari alternatif solusi yang memungkinkan. Permasalahan yang sedang terjadi yaitu sistem pembelajaran khususnya matematika yang sedang berjalan sekolah tersebut masih bersifat konversional atau manual. Pemeberian materinya masih manual juga dengan bertatap muka di dalam kelas. Maka dari itu perlu diadakan perubahan sistem yang lama menjadi sistem yang baru, sehingga lebih memudahkan guru dalam memberikan materi tambahan kepada siswa.

Aplikasi mobile learning ini dibuat untuk membantu proses penyampaian materi pada mata pelajaran matematika. Nantinya akan dibuat dua buah aplikasi yaitu aplikasi master dan aplikasi client. 


\section{Perancangan dengan model UML Use Case Diagram}

Use case diagram aplikasi mobile learning pembelajaran desain interior menggambarkan fungsi-fungsi apa saja yang akan di buat, baik itu pada aplikasi master maupun aplikasi client. Diagram use case aplikasi mobile learning dapat dilihat pada Gambar 1 berikut :

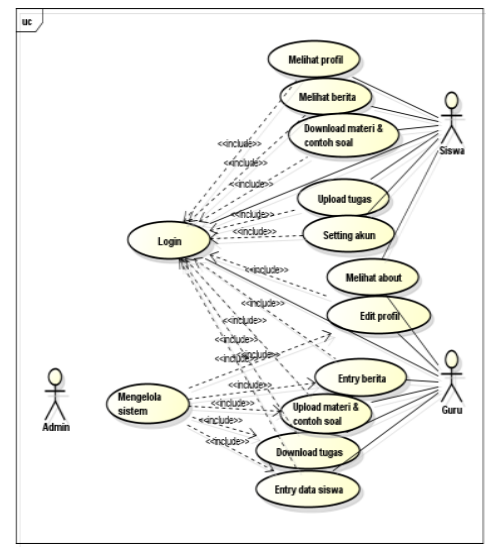

Gambar 1. Use Case Diagram

\section{Class Diagram}

Class diagram mendefinisikan kelas-kelas yang akan dibuat untuk membangun aplikasi mobile learning untuk mata pelajaran desain interior. kelas-kelas tersebut salah satunya adalah kelas main yang memiliki fungsi awal saat sistem dieksekusi. Diagram kelas dapat dilihat pada gambar 2.

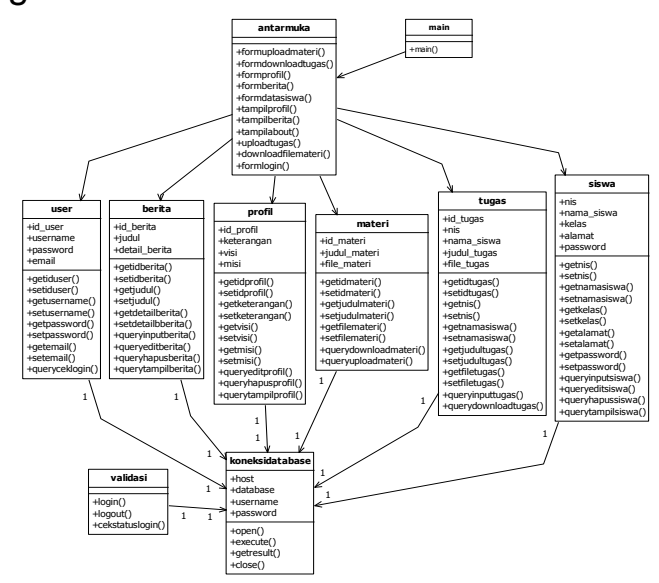

Gambar 2. Class Diagram

\section{Activity Diagram Client}

Diagram activity

client menggambarkan alur aplikasi untuk mengakses konten. Siswa merupakan user utama aplikasi client. Hal apa saja yang dapat di akses siswa tergambar pada diagram activity seperti Gambar 3 Berikut.

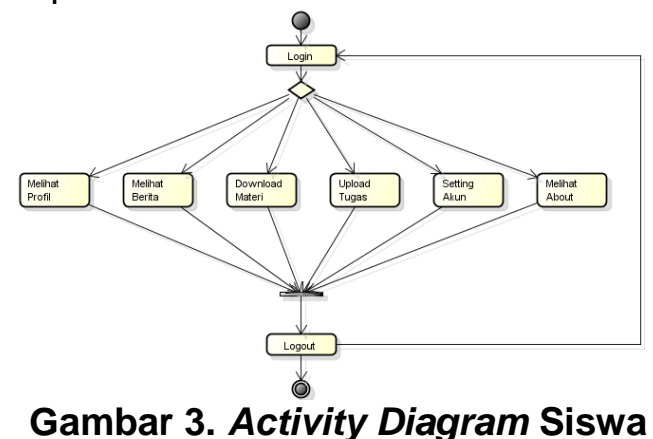

\section{Activity Diagram Server}

Activity diagram pada aplikasi master menggambarkan apa saja yang dapat dilakukan oleh guru. Hal apa saja yang dapat di akses guru tergambar pada diagram activity seperti Gambar 4 Berikut.

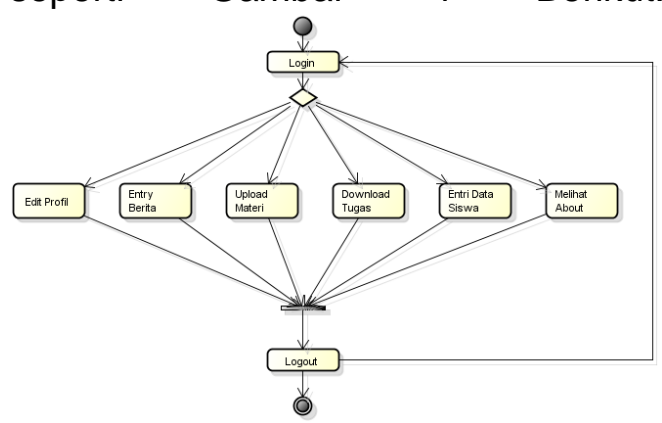

Gambar 4. Activity Diagram Guru

\section{IMPLEMENTASI SISTEM}

Implementasi sistem merupakan penerapan sistem yang siap digunakan. Dalam bab ini dijelaskan bagaimana menginstal aplikasi mobile learning pembelajaran matematika pada perangkat mobile berbasis android dan tampilan aplikasi saat dioperasikan pada perangkat mobile berbasis android. 


\section{Halaman Menu Login Admin}

Admin login dengan

menggunakan username dan password yang sudah didaftarkan. Halaman menu login dapat dilihat pada Gambar 5 berikut.

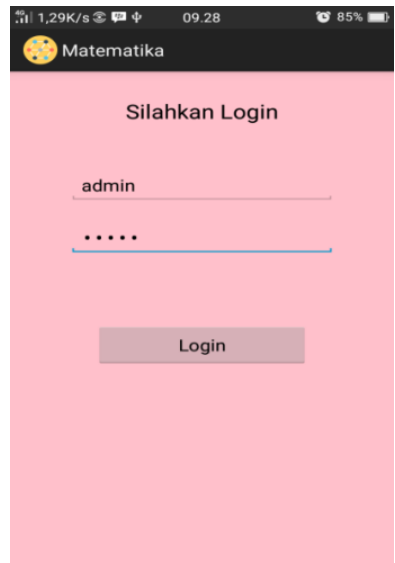

\section{Gambar 5. Halaman Menu Login}

\section{Halaman Menu Utama}

Pada halaman utama

ditampilkan menu-menu yang dapat dipilih pengguna seperti menu edit_profil, entry_berita, upload_materi untuk membaca materi, download_tugas untuk mendownloadtugas siswa dan menu tambah data siswa, kemudian menu about. Untuk lebih jelasnya halaman menu utama dapat dilihat pada gambar 6 berikut ini :

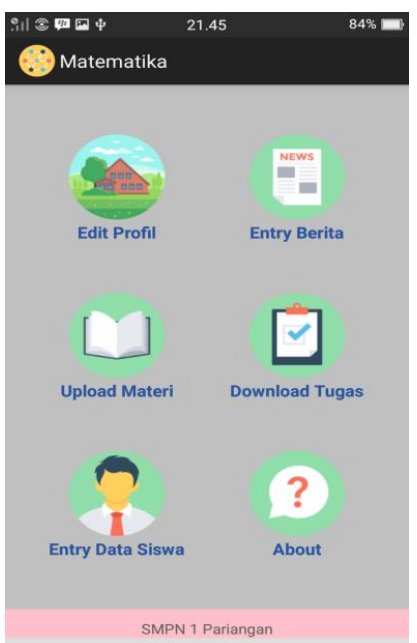

\section{Gambar 6. Halaman Menu Utama}

\section{Halaman Edit Profil}

Menu edit profil digunakan untuk mengubah data sekolah atau profil sekolah. Untuk lebih jelasnya menu edit dapat dilihat pada Gambar 7 berikut.

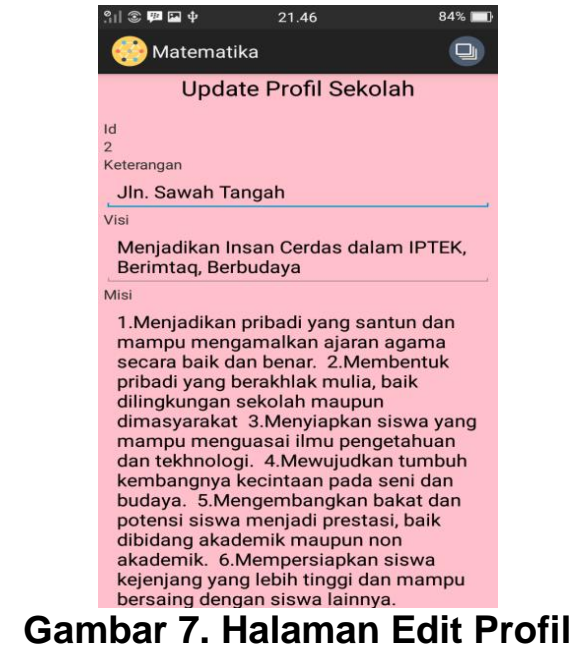

\section{Halaman Entry Berita}

Menu entry berita digunakan untuk memberikan pengumuman atau tugas kepada siswa.Untuk lebih jelasnya dapat dilihat pada gambar 8 berikut ini : 


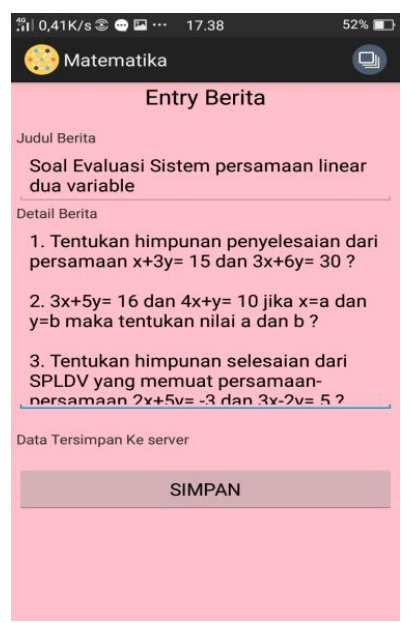

\section{Gambar 8. HalamanEntry Berita}

\section{Halaman Lihat Berita}

Menu lihat berita digunakan untuk melihat semua pengumuman yang masukan. Untuk lebih jelasnya dapat dilihat pada gambar 9 berikut ini:

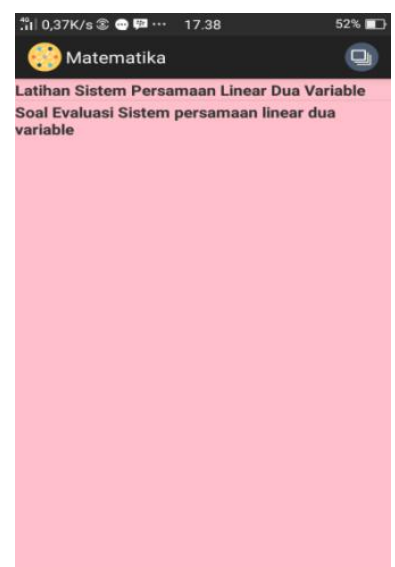

\section{Gambar 9. Halaman Lihat Berita}

\section{HalamanUpload Materi}

Menu upload materi digunakan untuk menambahkan materi. Untuk lebih jelasnya halalam dapat dilihat pada gambar 10 berikut ini :

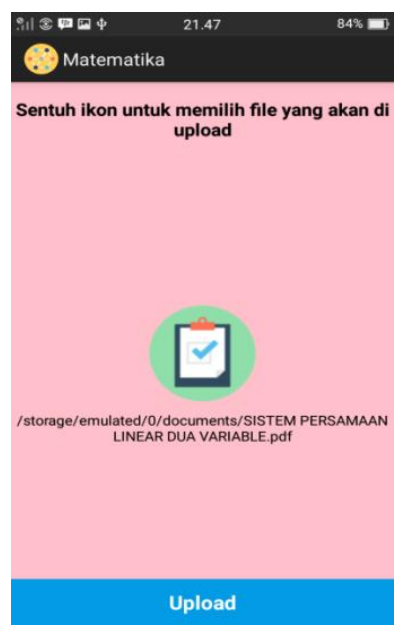

Gambar 10. Halaman Upload Materi

\section{Tampilan Antarmuka Download Tugas}

Menu download tugas akan menampilkan data tugasyang siswaupload yang telah tersimpan dalam database. Untuk lebih jelasnya halalam menu utama dapat dilihat pada gambar 11 berikut ini :

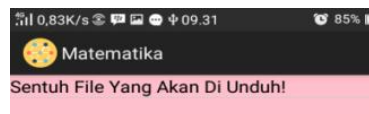

\section{Gambar 11. Halaman Download Tugas}

\section{Halaman Entry Data Siswa}

Menu entry data siswa akan menampilkan form berisi data siswa dari seorang siswa sesuai identitas nya yang telah tersimpan dalam database. Untuk lebih jelasnya 
halalam menu utama dapat dilihat pada gambar 12 berikut ini.

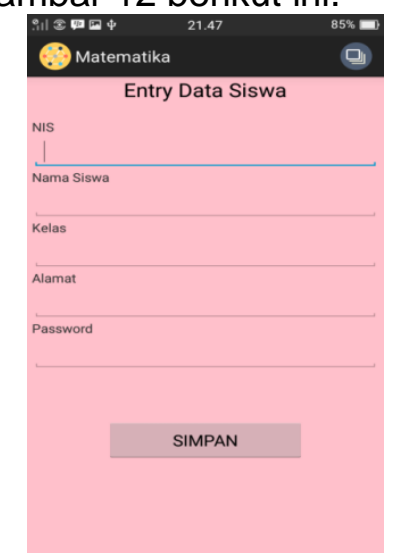

\section{Gambar 12. Halaman Entry Data Siswa}

\section{Halaman Lihat Data Siswa}

Menu lihat data siswa akan menampilkan data siswa dari yang sesuai identitas nya yang telah tersimpan dalam database. Untuk lebih jelasnya dapat dilihat pada gambar 13 berikut ini :

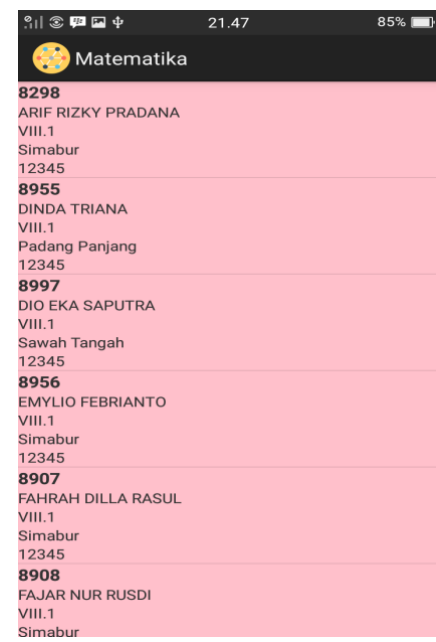

\section{Gambar 13. Halaman Lihat Data} Siswa

\section{Halaman Login User}

User login dengan menggunakan nis dan password yang sudah didaftarkan oleh admin. Untuk lebih jelasnya dapat dilihat pada gambar 14 berikut ini :

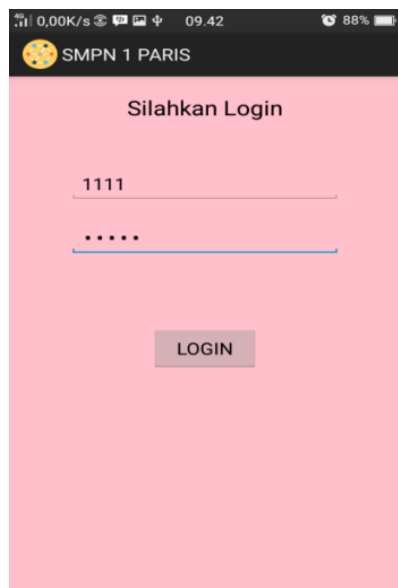

\section{Gambar 14. Halaman Login User}

\section{Halaman Utama User}

Pada halaman utama ditampilkan menu-menu yang dapat dipilih pengguna seperti menu profil sekolah, berita, download materi untuk membaca materi, menu tugas untuk mengupload tugas, setting akun dan about.Untuk lebih jelasnya dapat dilihat pada gambar 15 berikut ini :

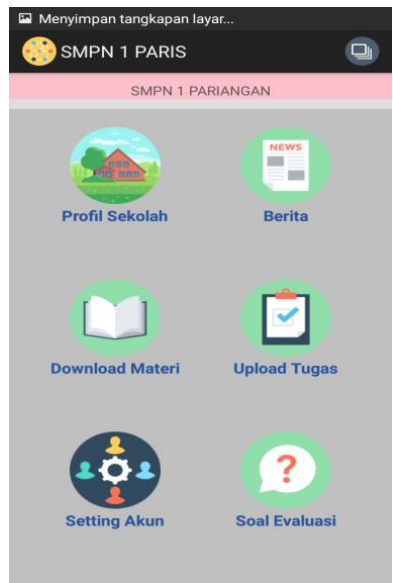

\section{Gambar 15. Halaman Utama User}

\section{Halaman Profil Sekolah}

Informasi tentang profil sekolah mulai dari nama sekolah, alamat sekolah, visi dan misi sekolah.Untuk lebih jelasnya dapat dilihat pada gambar 16 berikut ini : 


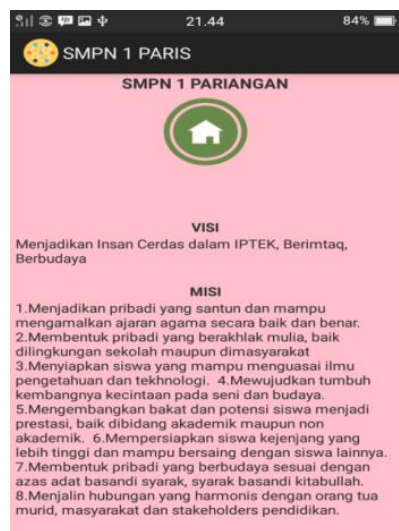

Gambar 16. Halaman Profil Sekolah

\section{Halaman Menu Berita}

Pada halaman menu berita, user dapat melihat ada berita atau tugas apa yang diberikan oleh guru. Untuk lebih jelasnya dapat dilihat pada gambar 17 berikut ini :

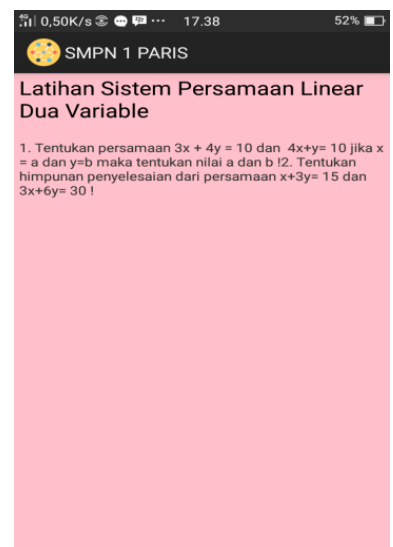

\section{Gambar 17. Halaman Menu Berita}

\section{Halaman Menu Download Materi}

User dapat mendownload materi dengan mengklikmenu materi. Untuk mendownload materi, user menyentuh ikon download, maka materi dapat dilihat .Untuk lebih jelasnya dapat dilihat pada gambar 18 berikut ini :

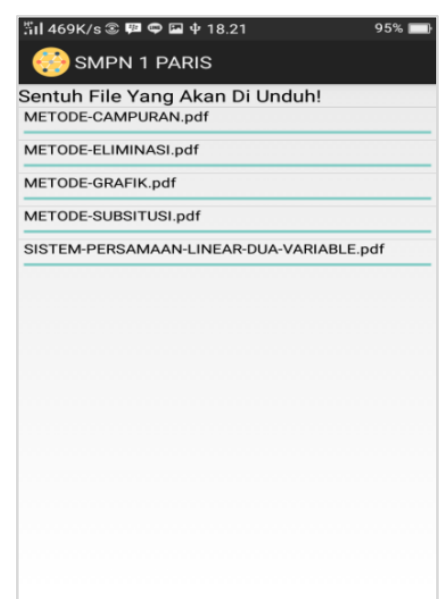

\section{Gambar 18. Halaman Download Materi}

\section{Halaman Menu Upload Tugas}

User dapat upload file dengan memilih menu tugas. Untuk mengupload file, user menyentuh ikon yang ada di dalam file tugas lalu mengisi format id tugas, judul tugas dan lokasi tugas. Untuk lebih jelasnya dapat dilihat pada gambar 19 berikut ini :

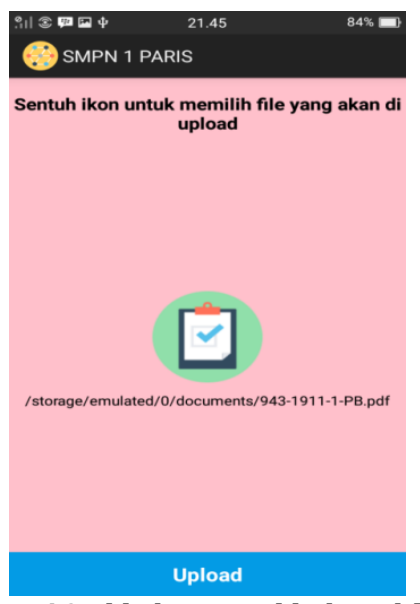

Gambar 19. Halaman Upload Tugas

\section{Halaman Setting Akun}

Menu Setting akun akan menampilkan form berisi data siswa dari seorang siswa sesuai identitas nya yang telah tersimpan dalam database.kemudian siswa bisa menganti password yang telah di 
entrykan oleh admin.Untuk lebih jelasnya dapat dilihat pada gambar 20 berikut ini :

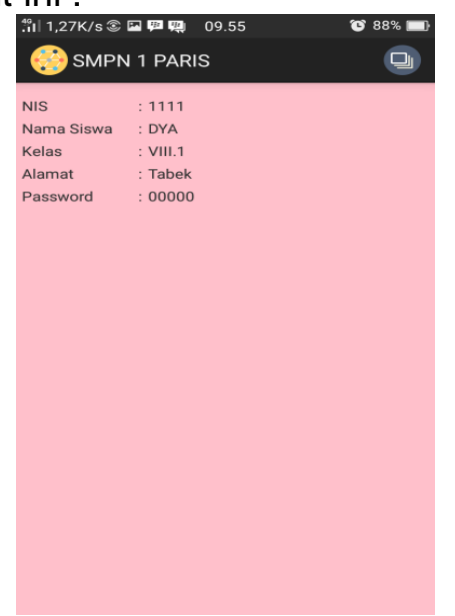

\section{Gambar 20. Halaman Setting Akun}

\section{Halaman Update Akun}

Menu Update akun akan menampilkan password dimana siswa bisa menganti password yang telah di entrykan oleh admin.Untuk lebih jelasnya dapat dilihat pada gambar 21 berikut ini :

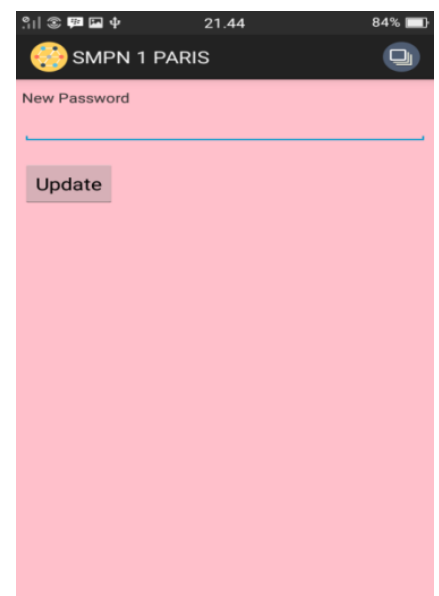

Gambar 21. Halaman Update Akun

\section{Halaman Menu Soal Evaluasi}

Menu soal evaluasi akan menampilkan form berisi tentang soalsoal mengenai sistem persamaan linear dua valriable.Untuk lebih jelasnya dapat dilihat pada gambar 22 berikut ini :

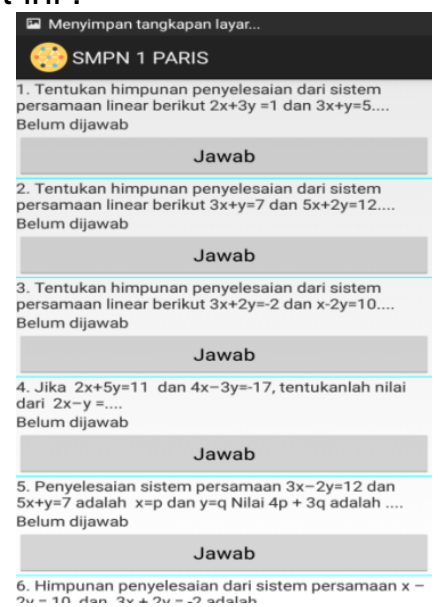

\section{Gambar 22. Halaman Menu Soal Evaluasi}

\section{KESIMPULAN}

analisa yang dilakukan sampai terbentuknya rancangan Aplikasi Mobile Learning tentang Pembelajaran di Matematika, maka penulis menarik kesimpulan sebagai berikut :

1. Aplikasi Mobile Learning tentang Pembelajaran Matematika khususnya sistem persamaan linear dua variable dapat diakses dengan perangkat mobile berbasis android milik pengguna, sehingga pengguna dapat belajar dimana saja dan kapan saja dengan menggunakan perangkat mobile.

2. Aplikasi Mobile LearningPembelajaran Matematika tentang sistem persamaan linear dua variable , siswa akan lebih mudah dalam mendapatkan bahan belajar karena pada aplikasi mobile learning juga ditampilkan bahan materi belajar dan contoh soal beserta pembahasannya.

3. Aplikasi Mobile Learning tentang Pembelajaran Matematika ini dapat di update kapan saja sehinggasiswa akan lebih mudah 
dalam mendapatkan materi yang baru pada perangkat mobile.

4. Aplikasi Mobile Learning tentang Pembelajaran Matematika ini, dapat membantu siswa dalam memperoleh informasi pengumuman maupun tugas dari guru karena aplikasi mobile learning ini terdapat menu berita dan menu upload tugas.

\section{DAFTAR PUSTAKA}

[1] A.S,Rosa. Shalahudin,M.2014. Rekayasa Perangkat Lunak Terstruktur dan berorientasi objek.Informatika : Bandung

[2] Enterprise,Jubile. 2014. Java untuk Pemula. PT.ElexMedia Komputindo : Yogyakarta.

[3] H, Safaat, Nazaruddin. 2014. Pemograman Aplikasi Mobile Smartphone dan Tablet PC Berbasis Android. Informatika : Yogyakarta

[4] MF, Mudzir. 2014. PHP Tutorial Book For Beginner. Yogyakarta: Notebook.

[5] Nuharini, Dewi. Wahyuni, Tri. 2008. Matematika Konsep dan Aplikasinya. Pusat Perbukuan Departemen Nasional : Jakarta.

[6] Pratama, IPutuAgus. 2014. Sistem Informasi dan Implementasinya, Teori Konsep Sistem Informasi Disertai Contoh Praktiknya Menggunakan
Perangkat Lunak Open Source. Informatika : Bandung

[7] Simarmat, Janner. Prayudi,Imam. 2010. Basis Data. Andi: Yogyakarta.

[8] Sutabri, Tata. 2012. Konsep Sistem Informasi. Andi : Yogyakarta.

[9] Fatma Sukmawati, M.Pd. "Perancangan Aplikasi Pembelajaran Biologi SMP

[10] Berbasis Android Untuk Bekal Menghadapi UAN Di SMP Islam Bakti 1Surakarta". Jurnal Teknologi Informasi. Vol XI. No 31 Maret 2016. ISSN 1907-2430.

[11] Liranti Rahmelina, Drs Legiman Slamet MT, Yasdinul Huda S.Pd, MT."Aplikasi Mobile Learning IImu Biologi Untuk Siswa Kelas $X$ Sekolah Menengah Atas Berbasis Android ( Studi Kasus SMA 10 Padang )". Jurnal Voteknika. Vol.2. No.2. Juli 2014. ISSN 2302-32.

[12] Muhammad Yusuf, Sri Wahyuni, Mohammad Sain. "E- Learning menggunakan Standar Learning Technology System Architecture (LTSA)". Jurnal elearning.Vol.1,No.2,2010. ISSN 2088-2130.

[13] Tri Listyorini, Anteng Widodo. "Perancangan Mobile Learning Mata Kuliah Sistem Operasi 
Berbasis Android". Jurnal Simetris, Vol.3, No.1, April 2013.ISSN 2252-4983.

[14] Yenni Anggrayi. "Perancangan Mobile Learning Berbasis J2ME untuk Penyediaan Bahan Ajar Perkuliahan Program Studi Pendidikan Ekonomi".Jurnal Sistem Informasi. Vol.4, No.1, April 2012. ISSN 2355-4611. 